\title{
THE EFFECT OF "STORYTELLING USING PUPPET" STRATEGY ON STUDENTS' SPEAKING ACHIEVEMENT AT EIGHTH GRADE OF JUNIOR HIGH SCHOOL IN SMP NEGERI 1 SERIRIT
}

\author{
Bayu I. G. B. C. \\ English Language Education, Ganesha University of Education, Singaraja \\ gusticandra94@yahoo.com \\ Piscayanti K. S. \\ English Language Education, Ganesha University of Education, Singaraja \\ sonia_pisca@yahoo.com \\ Paramartha A. A. G. Y \\ English Language Education, Ganesha University of Education, Singaraja \\ yudha.paramartha@undiksha.ac.id
}

\begin{abstract}
This study was purposed to investigate whether or not there was a significant effect of storytelling using puppet strategy on students' speaking achievement at eighth grade of junior high school at SMP N 1 Seririt in the academic year 2018/2019. The research design was Quasi Experimental of Posttest Only Control Group Design involving eighth grade students of SMP Negeri 1 Seririt. Cluster Random Sampling was assigned to select the sample of this study in which VIIIA Class was assigned as the control group and treated by using storytelling without puppet while VIIIB Class as the experimental group was treated by using storytelling with puppet strategy. Three kinds of instruments were used in this study namely lesson plan, speaking test, and storytelling rubric. Based on the result of the data analysis proves that there is a significant difference on students' speaking achievement between students who were taught by using storytelling with puppet strategy and those students who were taught by using storytelling without puppet strategy $(\mathrm{t}=4.942, \mathrm{df}=62, \mathrm{p}<0.05)$. Moreover, the result of the effect size in this study is 0.282 . It indicates that storytelling with puppet strategy give a large influence on students' speaking achievement. Referring to those results, it can be concluded that storytelling using puppet strategy can give significant effect on students' speaking achievement.
\end{abstract}

Keyword: Puppet Media, Speaking Achievement, Storytelling

\section{INTRODUCTION}

Speaking is one of the language skills that should be learned by the students in learning English. It is an ability to produce an oral language or a process of constructing meaning that involves producing, receiving, and processing the information that is obtained. Cameron (2001, p. 40) remarks that speaking is an active use of language that helps people express meanings so that the other can understand it. According to Bailey and Savage (1994) as cited in Praneetponkrang and Phaiboonnugulkij (2014) speaking a foreign language is the most required skill of four language skills and it also becomes a central skill among other skills. The ability to speak English is needed in order to be able to communicate and express ideas to the other people. This skill is considered a communication tool, in which the success or failure of the communication will be determined by this skill. Thus, if we can speak well, the listener will understand what we talk about easily (Siregar et al., 2014). To be able to use the spoken language well is required by students. Therefore, the need of practice using English in communication seems very necessary because it will help students to improve their speaking skill.

All students should be encouraged to speak English in the classroom, in order to familiarize them in using English and let them improve their ability in speaking the target language. According to 
Harmer $(2007$, p. 123) there are three reasons for getting students to speak in the class: first, it provides rehearsal opportunities for them to practice speaking in real-life situation. Second, speaking tasks let students to speak by using any or all the language that they already known. Thus, provide teacher and students feedback. Third, the more opportunities that students receive the more fluently of their speaking with the use of words and phrases without any confused thought. Another reason why students should be encouraged to speak is to train them to be familiar with the use of the target language. So, they will be able to use it in certain situation such as giving instruction, asking question, expressing opinion, explaining something, telling story, and so forth.

Nevertheless, speaking is still assumed by the students as one of the difficult parts in learning English. However, it is not totally true because there is one strategy that can help students learning speaking easily. Storytelling strategy is a strategy that can be used in teaching speaking. It is because storytelling strategy is very close to students' experiences and has connection with their life. They may remember about the story told by his/her mother especially, when they cannot sleep in the midnight, or the story about how they got the scare, etc. Basically, students like to hear story and like to tell story. As stated by Praneetponkrang and Phaiboonnugulkij (2014) retelling story can motivate students as well as assist them to view the content components of the message in which can connect to their experiences. Following that statement, Ahmadi and Mohamadi (2017) admit that storytelling is real experience and it gives a pleasure and attractive as well. Moreover, it is the earliest forms of knowledge transfer, and parents usually use it in order to teach their children about values and knowledge (Duveskog et al., 2012).

This strategy is well implemented in all levels of students start from kindergarten, elementary, junior high school or even in senior high school. According to Woodhouse (2008) storytelling is necessary given to the primary and secondary school students, it is because language is already established and it is time for them to deepen their language and practicing it. By applying storytelling strategy enhances students' interest. Therefore, allow students to become involved in the use of the target language (Nguyen et al., 2014). In addition, in teaching junior high school students, the use of simple language is recommended to adjust to their level. Hence, the story can be easily understood by students. The students can tell a story based on their experience, imagination, story that heard from somebody beforehand, story book, etc. However, when the students are asked to tell a story to their classmates, they need to be given a time for some preparation. As suggested by Harmer (2007) if students are asked to tell story, they need to be given time to think about what they are going to say. That is why students should be prepared before they are demonstrating the story by their own way.

Furthermore, storytelling strategy will be more powerful if it is accompanied by a proper media. Puppet can be used as a media to accompany the teacher as well as the students in telling stories. According to Setiawati (2017) puppet is a doll in which its head may in the form of person or animal and a cloth body, and it can be manipulated with the fingers of the puppeteers. It is an excellent resource or media for communication between a teacher and a student, as well as a student to another student (Korosec, 2013). This media is believed to enhance the students' involvement, motivation, and the development of student's reading, oral language, as well as communication skills (Maharani, 2016). Another benefit of puppet is presented by Prabakharan and Yamat (2017) who state that puppet can reduce students' anxiety in speaking and can change students' perception toward speaking English.

Based on the aforementioned information above about the characteristics of the puppet allows students to speak freely and reduce their anxiety, there might be a possibility that this strategy really worth to be applied in teaching speaking. However, the combination of puppet as a media and storytelling strategy has not been implemented yet, especially for students in junior high school. Therefore, considering those reasons, this present study will try to find out whether or not there is any significant effect of teaching storytelling strategy using puppet toward students' speaking achievement at eighth grade of junior high school in SMP Negeri 1 Seririt.

\section{METHOD}

The research design that was applied in this study was quasi experimental of posttest only control group design. There were two groups selected and they were assigned as the experimental group and the control group. The experimental group would receive a treatment of storytelling with puppet strategy and the control group was taught using storytelling without puppet strategy. In this type of 
research design, it only considered post-test score in data analysis. A post-test would be given to each group and the result of post-test would be measured in order to reveal whether or not there is any effect of students' speaking achievement between experimental group and the control group.

The population in this present study was from the eighth grade of junior high school in SMP Negeri 1 Seririt in the academic year 2018/2019. This grade was chosen as the population since they shared one characteristic, in which all of them were in the same grade of first semester. There are eight classes namely: VIII A, VIII B, VIII C, VIII D, VIII E, VIII F, VIII G, and VIII H. Each class contains 32 students, then, the total numbers of students' population were 256 students.

Furthermore, the technique sampling used in this study is cluster random sampling. This sampling is used since individuals in the population have been classified into several classes. Therefore, the classes should be chosen randomly by using lottery. This technique is also used to decide which classes belong to the control group and which belong to the experimental group.

Before the treatment given, the researcher tested the students' previous score in order to know that both classes have no significant difference. The students' scores were obtained from the core English teacher in the school. Those scores were analyzed by using IBM SPSS Statistics 20 program to make sure that both of the classes have the same characteristics. This test is important to make sure that the final result obtained was accurate. So, the researcher could see further whether the storytelling using puppet strategy gave significant effect or not. However, before conducting this test (t-test), the researcher should administering normality and homogeneity test first. Shapiro-Wilk test was used to prove that the classes were normally distributed. In addition, Levene statistic test was used to find out the homogeneity of variances.

Based on the result of the Shapiro-Wilk test in this study before the treatment given, the significant value (Sig.) of VIII B class was 0.131, and the significant value (Sig.) of VIII A class was 0.411. Based on those result, it indicates that the significant value of both groups had exceeded 0.05 , which means that the two classes or group were in normal distribution. Moreover, the result of the Levene statistic test was 0.451 . It is clearly means that the variances of both of the classes were homogeneous.

After the two tests were analyzed, then it was necessary to administer t-test in order to find out whether or not both classes had no significant difference or had equal level before given the treatments. Based on the result of the independent sample test, the score of the significant value (2tailed) was .471 which means higher than the alpha level of significance (.05). It could be noticed then, the two groups or classes in this study have no significant difference or in other words, the two classes can be used as samples of the study. Next step is decided the two classes which one belong to experimental group, and which one belong to control group by using lottery. The result of the lottery showed that VIIIA Class was assigned as the control group and would be treated by using storytelling without puppet strategy. Meanwhile, VIIIB Class was assigned as the experimental group and would be treated by using storytelling with puppet strategy. Both of the group contain 32 students, so, the total number of students was 64 students.

There are two kinds of variables namely independent variable and dependent variable established in this study. According to Tuckman (1999, p. 93) independent variable is the ones that is measured, manipulated, and selected by the researcher to determine its relationship to an observed phenomenon. On the other hand, a dependent variable is the ones that is observed as well as measured to determine the consequent of the independent variable. Based on the explanation, the independent variable that exists in this study is teaching storytelling strategy using puppet whereas the dependent variable in this study is students' speaking achievement

In this study there are three kinds of instruments used namely lesson plan, speaking test, and storytelling rubric. Lesson plan is the first instrument used; it is one of the important instruments when conducting teaching and learning process. It was used as the guidance for the teacher in conducting the lesson. The second instrument is speaking test. Speaking test that is selected in this study related to the type of extensive speaking. It is chosen as post-test in this study. Extensive is one of the basic types of speaking where students are able to perform monologue, storytelling, oral presentation, and speeches (Brown, 2004, p. 141). And the last instrument is storytelling rubric. It is used as scoring direction to assess the students' performance in telling story. A rubric defines as an explicit set of criteria which is used for assessing a particular type of performance or work. The students will be assessed their performance in telling story in front of the class with their group. Their 
storytelling was evaluated by considering four criteria in the rubric such as content and organization, fluency, accuracy, and body language.

The first criterion was content and organization which has a weight of $40 \%$; in this part, students should know how to develop the opening, body and closing of the story as well as how they are supported by supporting details provided by the speaker. The second criterion was fluency with a weight $25 \%$; it means that the students should be able to use the language communicatively without interruption and only a small number of pauses such as "emm", "eerr", etc. the third criterion was accuracy and it has a weight 20\%; here, the students are supposed to use a clear and accurate pronunciation, grammar, and vocabulary. They have to know how to use an appropriate language while telling a story so that the meaning can be understood by the others. And the most importantly the students know how to speak the words clearly and accurately. Then, the last criterion was body language; this criterion has a weight $15 \%$ which requires students to be able to know how to use meaningful body movement includes facial expression, gesture, and eye contact so that the delivery of the story is well maintained. Those are the criteria that should be considered by the raters when scoring the students' performance in storytelling. Before the instruments were used, those instruments must be checked their validity and reliability.

This study, the researcher already tested their validity and reliability by conducting expert judges and try-out test. Content validity was used to measure the validity of the content whether the contents were appropriate to their level or not. There were two lectures of English Language

Education, Ganesha University of Education (UNDIKSHA) were asked to examine the instrument through their judgments. After that, their judgment would be compared and analyzed by using Gregory's formula. In addition, the tryout test also assigned in order to know that the instruments used were reliable before it is used further. The tryout conducted in SMP Negeri 1 Seririt with 32 participants of eighth grade students in VIIIC class. In order to avoid subjectivity, besides the researcher, the core English teacher in the school also was asked to contribute in assessing the students' performance in storytelling. Then, the scores from the two raters were analyzed to see their consistency and reliability.

Based on the result of calculation through Gregory's formula showed that the content validity was 1. It indicates that the instrument in this study can be classified had a very high content validity.

Besides that, the result of intraclass coefficient from the two raters in average measures was 0.965. It indicates that the result of reliability of the instruments is more than 0.80 and less than 1.00 $(0.80<\mathrm{R} \leq 1.00)$. It can be conclude that the instrument used in this study has very high reliability. Therefore, those instruments could be used in this study.

Since the instruments used in this study are reliable, the researcher can start doing investigation toward the storytelling using puppet strategy to find out whether or not the strategy give significant effect on students' speaking achievement. The technique of the data analysis used in this study was in the form of students' score. The scores from the two groups were analyzed descriptively and inferentially. In descriptive analysis includes mean, media, mode, range, standard deviation, and variance.

On the other hand, the data were analyzed inferentially that is by conducted t-test. Inferential statistic was provided in order to help the researcher to generalize the strategy which is experimented in this study. Inferential statistical analysis leads to judgments about the whole population, to which the sample at hand is presumed to be related (Best and Kahn, 1998, p. 379). This study generalizes the effect of storytelling using puppet strategy on students' speaking achievement. The aim of this analysis is to make a conclusion about the population based on the observations of the sample. It is also aimed to prove that the two classes did not have significant difference or has the same characteristic.

Normality test was used in order to know whether or not the distribution of the data was normal. In normality test, Shapiro-Wilk statistic would be used. This test was administered to prove that the classes were normally distributed. If the significant value of the data was less than 0.05 , it means the distribution of the data was not in normal distribution. On the other hand, if the significant value exceeded the value of 0.05 , the data could be categorized as normally distributed.

Homogeneity test was conducted to investigate whether the variance of the data were homogeneous or not. In testing homogeneity of variance of the data, levene statistic was 
administrated. Similar with normality test, if the significant value of the obtained data shows less than 0.05 , it means that the data were not homogeneous. Whereas, if the significant value was higher than 0.05 , it means that the variances of the groups were considered homogeneous.

After the data is already proven as in normal distribution and homogeneous, then, parametric test of independent sample test or commonly known as t-test can be conducted. T-test was conducted in order to test the hypothesis of the study. The hypothesis in this study is null hypothesis (Ho) namely: there is no significant effect of teaching storytelling using puppet strategy on students' speaking achievement at eighth grade of junior high school in SMP Negeri 1 Seririt in academic year $2018 / 2019$.

In addition, the researcher also administering the effect size tests. According to Pallant (2016) effect size gives an indication of the magnitude of the differences between the two groups study. In other words, it is used to measure the treatment effect. There are a number of statistical measures of difference effects, the most commonly used were eta squared and Cohen's d. Criteria of Cohen's $d$ are used as guidelines in order to interpreting the value of the effect size.

Table 1. Criteria of Cohen's d

.01

Small Effect

(1)

$.06 \quad$ Large Effect

Moderate Effect

.14

\section{FINDINGS AND DISCUSSION}

In this study, the treatment was conducted six times for each group and one meeting for their post-test. The total meetings that have been conducted were seven meetings. This study began on the $13^{\text {th }}$ July and finished on $15^{\text {th }}$ August 2018 . Two classes from eighth grade were selected as a sample of the study. And they were also assigned as an experimental class and control class. The experimental group was treated by using puppet media; meanwhile the control group was treated without puppet media. The two groups were given the same post-test after finishing the treatment. Their post-test was about telling story (storytelling) in front of the class with their group. The experimental group told story with puppet media whereas the control group told story without puppet. Both of the group performances were assessed by the core English teacher in the school and the researcher in this study.

Furthermore, two types of statistical analysis namely descriptive statistical analysis and inferential statistical analysis were presented to analyze the obtained data. Descriptive statistics this study provides information about the findings of the measures of central tendency namely, mean, median, and measures of dispersion such as range, variance, standard deviation, and mode. Meanwhile, the inferential statistics is used to infer and make conclusion about the population based on the sample of the data. The result of the data description can be seen below:

Table 2. The Result of Descriptive Analysis of Posttest Score

Experimental

\section{Statistics}




\begin{tabular}{lrr}
\hline N & 32 & 32 \\
Min. & 80.00 & 70.00 \\
Max. & 100.00 & 95.00 \\
Mean & 88.183 & 81.171 \\
Median & 86.875 & 80.625 \\
Mode & 85.00 & 82.50 \\
Range & 20.00 & 25.00 \\
Variance & 27.504 & 36.914 \\
Std. & 5.244 & 6.075 \\
Deviation & & \\
\hline
\end{tabular}

Based on the result of the data description presented above in the table 2, it was found that the mean score of the students in the experimental group was clearly higher if it is compared to the mean score of the control group. The mean score of the experimental group was 88.183 meanwhile; the mean of the control group was 81.171. It indicated that the different treatments given to the experimental group and the control group had significant difference in the result of the mean score.

Besides mean, the difference score could be seen in the following statistics includes median, mode, range, variance, and standard deviation. The median score of the experimental group study was 86.875 meanwhile, the control group obtained 80.625 from these score obtained, it showed that the middle score of the experimental group was clearly higher that the control group study. Mode of the experimental group was 85.00, while mode of the control group was 82.50. It could be assumed that the most frequently score appeared in the experimental group was higher than in the control group. The range score of the experimental group was 20.00 whereas the control group was 25.00. Variance of the experimental group was 27.504 whereas the variance of the control group was 36.914. It indicated that the score of the students in control group were more spread out compared to those students in experimental group. And the last was the score of the standard deviation of the experimental group was 5.244 while the standard deviation of the control group was 6.075. It showed that the experimental group had lower standard deviation than the control group, which meant that the mean of the students taught by using storytelling with puppet media were produced better score than teaching using storytelling without puppet strategy.

From the result of the descriptive statistical analysis, it could be noticed that the students in the experimental group had better performance than the students in the control group in relation to the students' speaking achievement.

Moreover, the researcher also conducting normality test to make sure that the distribution of the data were in normal. In order to do that, Shapiro-Wilk statistic was used to test whether or not the data were distributed normally. In Shapiro-Wilk test, it was assumed that the variances of group were in normal distribution when the significant value (sig.) exceeded 0.05 . The result of the Shapiro-Wilk statistic test could be seen below:

Table 3. The Result of Normality Test after Treatment

\begin{tabular}{lllll}
\hline \multicolumn{1}{c}{ Media } & \multicolumn{2}{c}{ Shapiro-Wilk } & \\
\hline & & $\begin{array}{c}\text { Statis } \\
\text { tic }\end{array}$ & df & Sig. \\
& Storytelling & .936 & 32 & .058 \\
Score & & & \\
& $\begin{array}{c}\text { with Puppet } \\
\text { Storytelling } \\
\text { Without } \\
\text { Puppet }\end{array}$ & .962 & 32 & .317 \\
\hline
\end{tabular}


Based on the table 3 above, the result of the sig. value of both groups had exceeded 0.05 . Therefore, it could be said that the data distribution from between the two groups were normally distributed.

In this research, Levene statistics was used to know the homogeneity of the variance. In the Levene statistics, the data variance of experimental group and control group were considered as homogeneous if the significance value (Sig.) is higher than value 0.05 . If the significance value is less than value 0.05 , the data variance of the experimental group and also control group is not considered as homogeneous. Based on the levene statistics test that has been conducted previously, the result could be presented as follows:

Table 3. The Result of Homogeneity Test after Treatment

\begin{tabular}{|c|c|c|c|}
\hline $\begin{array}{l}\text { Levene } \\
\text { Statistic }\end{array}$ & df1 & $\mathrm{df} 2$ & Sig. \\
\hline .085 & 1 & 62 & .772 \\
\hline
\end{tabular}

Based on the table 4, the significant value of both groups had exceeded the value 0.05 . From the table above, the significance value (Sig.) of the experimental group and also control group was 0.772. Therefore, it could be concluded that the variances between two groups were already homogenous. After it was proven that the data were in normal distribution and homogeneous. Then, the hypothesis testing was administered by using inferential statistical analysis (t-test) in order to know whether or not there was a significant effect of storytelling using puppet strategy on students' speaking achievement at eighth grade of junior high school at SMP N 1 Seririt in the academic year 2018/2019. The result of the independent sample test could be seen further below:

Table 5. The Result of Independent Sample t-test after Treatment

\begin{tabular}{lr}
\hline \multicolumn{1}{c}{ Statistics } & Value \\
\hline & \\
T & 4.942 \\
Df & 62 \\
Sig. & .000 \\
Mean Difference & 7.011 \\
Remark & Significant \\
\hline
\end{tabular}

Based on the result of the independent sample test (t-test) above, it was found that the score of the significant value (2-tailed) was .000 which means less than the alpha level of significance (.05). It also indicates that the null hypothesis (Ho) in this research was rejected. Therefore, it could be said that there is significant effect on students' speaking achievement between students who have been taught using storytelling with puppet strategy and those who have been taught using storytelling without puppet strategy in eighth grade students of SMP Negeri 1 Seririt in academic year 2018/2019.

Furthermore, besides the result of the t-test showed significant, the researcher also administering the effect size. The calculation of the effect size could be seen below:

$\mathbf{t}^{2}$

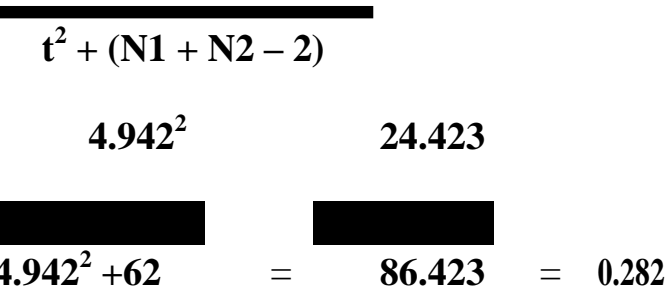

Figure 1. Calculation of the Effect Size 
Based on the figure 1 above, it shows that the result of the effect size is 0.282 . Then, it can be categorize as large effect. It means that teaching storytelling with puppet media give a large influence on students speaking achievement.

In addition, during the implementation of different treatments for both groups, it was very clear that both of the groups showed different response toward the teaching and learning activity. In the control group, the students were excited at first however, they easily get bored in the middle. And they did not pay attention to their friends while telling story and even some of them were talking with their friends. In contrast, the experimental groups were more excited and very enjoy in listening to the story from the beginning to the end. The students were enjoyed seeing their friends playing the puppet that helps them easily understood the story. They were not afraid if they were asked by their teacher to perform.

Referring to the result of this study, it could be emphasized that the experimental group showed better performance as well as better achievement in speaking compared to the control group. It indicates that puppet was an effective media for teaching speaking. The media helps the students easy to learn speaking. It creates the learning activity more enjoyable in which let people or in this case students who work with this media was not afraid to speak.

\section{CONCLUSION}

Based on the finding and the discussion above, it was found that storytelling with puppet strategy gives significant effect on students' speaking achievement. Students were more excited in teaching and learning process and they easier to learn language because the media help students release their fear. During the treatment given to the both groups, the researcher could noticed that students more confident in storytelling without something to be afraid of compared to the students who taught by using storytelling without puppet media which tend to be afraid for making mistake and they were shy when they were asked to perform in front of the class. As a result, they could not maximize their performance. In addition, it also confirmed by statistical analysis. It was showed that the result of the mean score of the experimental group study was higher if it is compared with the mean score of the control group. The mean score of the experimental group was 88.183 meanwhile the control group was 81.171. Moreover, the inferential statistics analysis showed that the score of the significant value (2-tailed) was 0.000 . It was less than the standard alpha $(a=0.05)$. Then, it could be confirmed that the null hypothesis was successfully rejected and the alternative hypothesis was accepted. For those reasons, the result of this, study can be concluded that there was a significant effect on students' speaking achievement between students who were taught by using storytelling with puppet strategy and those who were taught by using storytelling without puppet strategy at eighth grade students of junior high school in SMP Negeri 1 Seririt in academic year 2018/2019.

\section{REFERENCES}

Ahmadi, R., and Mohamadi, Z. (2017). The Effect of Storytelling through Puppets on Speaking Fluency and Motivation of pre-intermediate Iranian English as Foreign Language Learners. Teaching English Language Studies, 5(4), 65-102.

Best, J. W., and Kahn, J. V. (1998). Research in education (8th ed.). Boston: Allyn and Bacon

Brown, H. D. (2004). Language Assessment: Principles and Classroom Practices. United States of America: Pearson Education, Inc.

Cameron, L. (2001). Teaching Language to Young Learners. The Practice of English Language Teaching. New York : Cambridge University Press.

Duveskog, M., Tedre, M., Sedano, C. I., and Sutinen, E. (2012). Life Planning by Digital Storytelling in a Primary School in Rural Tanzania. Educational Technology \& Society, 15(4), 225-237. 
Gay, L. R., Mills, G. E., and Airasian, P. W. (2012). Educational Research: Competencies for Analysis and Applicationts (10th ed.). Boston: Pearson Education.

Harmer, J. (2007). How to Teach English. England: Pearson Education.

Korosec, H., and Korošec, H. (2013). Evaluating Study of Using Puppets as a Teaching Medium in Slovenian Schools. Školski vjesnik, 62(4), 495- 520.

Maharani, S. (2016). The Use of Puppet: Shifting Speaking Skill from the Perspective of Students' Self-Esteem. Register Journal, 9(2), 101-126.

Nguyen, K., Stanley, N., and Stanley, L. (2014). Storytelling in Teaching Chinese as a Second/Foreign Language. Linguistics and Literature Studies, 2(1), 29-38.

Pallant, J. (2016). SPSS Survival Manual: A Step By Step Guide to Data Analysis Using SPSS Program ( $6^{\text {th }} E d$.). London, UK: McGraw-Hill Education.

Prabhakaran, D., and Yamat, H. (2017). Speaking Anxiety: Discover the Power of Puppet. Education and Social Sciences, 6(1), 79-87.

Praneetponkrang, S., and Phaiboonnugulkij, M. (2014). The Use of Retelling Stories Technique in Developing English Speaking Ability of Grade 9 Students. Advances in Language and Literacy Studies, 5(5), 141-154.

Setiawati, S. (2017). Using Puppet as Media to Increase the Children Vocabulary. Jurnal Pendidikan Al-Ishlah, 8 (4), 257-269.

Siregar, N. R., Ernati, and Tavriyanti, L. (2014). Teaching Speaking by Using Puppet Play for Junior High School Students. The Faculty of Teacher Training And Education of Bung Hatta University, 3(6), 1-10.

Tuckman, B. W. (1999). Conducting Educational Research: Fifth Edition. United States of America: Harcourt Brace College.

Woodhouse, J. (2007). Storytelling and Narratives: Sitting Comfortable with Learning. Strategies for Healthcare Education: how to teach in the 21 ${ }^{\text {st }}$ Century, 61-70. 